\title{
Internet-driven changes in environmental NGO action
}

\author{
Pedro Pereira Neto
}

Instituto de Ciências Sociais, Universidade de Lisboa, pedro.neto@ics.ul.pt

\begin{abstract}
Information and Communication Technologies, considered both as a technological resource and as a social technology, play an important role in the shaping of existing social relations and in the creation of new modes of interaction and social organization (AA. VV., 2000). However, traditional approaches of political action frequently misstate just how politically active citizens are by underrating changes occurred in the realm of political mediation (Norris, 2002, p. 2; Epstein, 1991, p. 230). The changes in the organizational and action repertoires go hand in hand with the specificities of each NGO's cultural interpretative devices, which are influenced by technological change (Zald, 1996, p. 266-270). On the other hand, frames are also subject to internal debate, a process in which ICTs also take part (Webster, 2001, p. 7). Hence, this paper focuses on clarifying the ways in which NGOs have their structure and action repertoires changed by the use of ICTs.
\end{abstract}

Keywords: ICT, Internet, NGO, Environmentalism

\section{Introduction}

M odern societies stand in our times in the face of two parallel processes: on one hand, the decline in the Gemeinschaft's geographical significance; on the other hand, the setting of communicative ties between citizens geographically distant from one another (Webster, 2001, p. 9). In an age where events taking place in different continents influence the lives of populations however distant they may live (Tarrow, 1996, p. 53), Information and Communication Technologies, considered both as a technological resource and as a social technology, play an important role in the shaping of existing social relations and in the creation of new modes of interaction and social organization (AA. VV., 2000).

However, traditional approaches of political action - such as party militancy, union vigour, and elections - frequently misstate just how politically active citizens are by underrating changes occurred in the realm of political mediation (Norris, 2002, p. 2; Epstein, 1991, p. 230). The changes in the organizational and action repertoires go hand in hand with the specificities of each NGO's cultural interpretative devices, which are influenced by technological change (Zald, 1996, p. 266270). On the other hand, frames are also subject to internal debate, a process in which ICTs also take part (Webster, 2001, p. 7). The very idea that influence can be played over a political system from outside it is, actually, behind ICT use in such organizations (Castells, 1997; Norris, 2002, p. 10).

Hence, this paper deepens earlier work the author has conducted, with a main focus on clarifying and understanding the ways in which NGOs as citizenship practices have their structure and action repertoires changed by the use of ICTs. Among the main questions underlying this intention are

a) how are ICTs seen by activists within NGOs, and what variables are there behind such representation of ICTs?,

b) how are ICTs integrated by NGOs, and how is the latter's practice changed by such integration?, and 
c) how have the national legal framework and the shape of the Portuguese political system shaped such integration?

In order to tackle these questions a threedimensional approach, encompassing the strong points of three different but compatible theoretical standpoints, will be proposed in Chapter 2. This approach is then described, both in its defining terms and in its outcome, in sub-chapters 2.1 - which deals with a macro-level analysis -, 2.2 - dealing with a medium-range or meso-level analysis -, and 2.3 - dealing with micro-level analysis. A sumup of the answers and overall picture is presented in sub-chapter 2.4, before concluding remarks are made.

\section{Social movements: a three- dimensional approach}

Considered to be "windows into possible futures", social movements have, in the last few decades, increased both in number and diversity (Rocher, 1977-1979, p. 119; Maheu, 1993, p. 105; Melluci, 1995, p. 433). Yet, the intensity of citizens' political action is frequently underrated by analysis focusing mainly - if not exclusively - on party militancy, union vigor or vote turnout (Norris, 2002, p. 2; Epstein, 1991, p. 230).

From the social movements risen in the $60 \mathrm{~s}$ and 70 s, the environmental movements are considered to exert the biggest and more enduring influence over the political system, a phenomenon with two main underlying causes: on one hand, by promoting cultural and structural decentralization issues; on the other hand, such issues signal the existence of a systemic problem which can only be dealt by refusing linear causalities and encompassing a range of approaches and subsequent variables (Dalton, 1995, p. 296; Garner, 1996, p. 5; Melucci, 1996, p. 163; Castells, 1997; Rootes, 1999, p. 1).

Social movements vary considerably in their ideology, goals, size, scope, social base, structure, and action repertoire. Such diversity cannot but influence the ways in which ICTs are used, and consequently, the approaches one can adopt in order to fruitfully analyze them (Van de Donk \& Rucht, 2002). If social structures and cultural frames are inseparable, and collective action dialectic since it encompasses systems and actors, it makes sense to believe ICT use can best be understood when several theoretical approaches are articulated and each other's limitations - mainly their excessive analytical narrowness - surpassed, addressing variables such as structural constraints, context of political and social opportunity, mobilized resources, and symbolic interpretation and framing processes (Maheu, 1995, p. 11; Calhoun, as cited in Neveu, 1996, p. 74; Garner, 1996, p. 5; Smelser, as cited in Garner, 1996, p. 62-63).

To this end an analytical framework is proposed in which three dimensions come together: at a macro-social level, contextual power alignment and distribution are addressed; at a meso-social, organizational and instrumental constraints are kept in mind; and at a micro-social level, symbolic interpretations and individual predispositions for action are dealt with (Rosenau, 1993, p. 262).

With this analytical framework in mind, four ENGOs were scrutinized: LPN $^{1}$, an organization with nationwide scope and reach, and one of the most centralized structure; GEOTA $^{2}$, a nationwide NGO based on protocols with local organizations; Quercus, a nationwide organization decentralized through own local branches; and $\mathrm{GAIA}^{3}$, a universitybased NGO with local/regional reach.

Contact with these ENGOs was two-fold. On one hand, through centered interviews with individual representatives playing top institutional roles and a long record of membership (assuring a close knowledge of internal NGO mechanisms), allowing for the analysis of the way in which these actors view and (re)construct both individual, collective and organizational action and processes (Quivy \& Van Campenhoudt, 1998, p. 193194). On the other hand, through the analysis of both inward and outward pre-existing documentation, collected in situ and taken from these ENGOs' websites, following Castells' insight on conceiving institutional discourse as a self-definition process

Liga para a Protecção da Natureza.

Grupo de Estudos de Ordenamento do

Território e Ambiente.

3 Grupo de Acção e Intervenção Ambiental. 
(Castells, 1997). Whenever possible GEOTA and GAIA -, attendance of work meetings was also used.

\subsection{Macro-analysis: the role of political and economical opportunity structure}

If we consider NGO as political actors developing rational efforts to change their context, the circumstances underlying their action become central to any analysis (Marx, 1963 , p. 15; Garner, 1996, p. 28; Giugni, 1999 , p. 28). Although they do not explain collective action by themselves, factors such as the stabilization of democratic regimes, the decomposition of class-based social structures, changes in citizens' values and in traditional political representation are determinant for the definition of NGO strategies (Crook \& Pakulski \& Waters, 1992, p. 141-142; Dalton, 1993, p. 41; Pakulski, 1995, p. 70; Garner, 1996, p. 28; Tarrow, 1998, p. 199-200; Giugni, 1999, p. 18-27).

The first Portuguese ENGO, LPN, was created only in 1948 mainly given the national political context - a dictatorship - and its effect over the civil society associative dynamics (Soromenho-Marques, 2002, p. 9293). On the other hand, since environmental collective action has historically been intertwined with Industrialization, it should be noted that Portugal only developed its industrial sector from the $50 \mathrm{~s}$ onward (Soromenho-Marques, 2002, p. 106).

A newcomer to the set of democratic regimes and a member of the EU only since 1986 , the country is undergoing a transition to an information-based economy and to "European" life standards and post-modern values, such as environmental ones (Cardoso, 1998). Nevertheless, environmental political performance in Portugal according to the OECD is still meager, namely in terms of policy ambition and ecological parties' political influence (Rucht, 1999, p. 210-220).

Such absence of influence, played both in terms of a discontinuity between ENGOs social base and political influence and in terms of difficulties in establishing cooperative ties between governmental institutions with centralized decision-making processes and NGOs, became visible in the context of the debate regarding the placement of the Vasco da Gama bridge, in Lisbon (SoromenhoMarques, 2002, p. 106-126; Vasconcelos, 2002, p. 132), rendering "setting the agenda extremely difficult" according to Joanaz de Melo (LPN).

\subsection{Medium range analysis: the role of the technological infrastructure as a resource}

Most events in the lives of citizens take place in contexts decisively influenced by Information, considered one of the key elements in contemporary conflicts and exercise of power (Maheu, 1995, p. 113; Melucci, 1995, p. 434-436; Mansell, 2001; Silverstone, 2002). On the other hand, ENGOs must adapt to the context in which they develop their action (Vasconcelos, 2002, p. 135).

Such is the position held by GEOTA in its "Tecnologias de Informação para o GEOTA" report. According to this document, since Information is considered a significant element of GEOTA's raw materials and end product, the opportunities raised by the current technological context may foster the organization's development and future intervention capacity (GEOTA, 2002, p. 4).

On the subject of adaptation to ICTs in use throughout society, Quercus' official Francisco Ferreira had this to say:

"All the communicative practice and idea spreading by Quercus has been in close relation with aspects of innovation and technology introduction in society. Cell phones, e-mail, all things which are part of the process of adaptation Quercus had to pursue in order to answer to a set of immediate challenges. Earlier time response was too long".

According to Hélder Careto, a greater use of ICTs by GEOTA depends on own "technological and financial resources, since there already exist the required infrastructures in the country". But not everyone shares this view: Gualter Baptista stated that "if Portugal had better Internet networks, GAIA would probably have its work eased".

On a parallel record, according to OberCom (2007), less than half (42\%) of the Portuguese population uses the Internet on a regular 
basis. Baptista acknowledges this context, sustaining that although the potential benefits of ICT use by GAIA are being met, there is still a considerable number of people with which this NGO deals that have no e-mail checking routines.

Ferreira points out that opportunities arising from ICT use by Quercus are not fully met, since a few technologies that could be of importance to this NGO are not widespread yet, such as video-conferencing: "it would take everyone to possess those means at home".

According to OberCom (2008), Portuguese nationals below 24 years of age are the ones who use the Internet the most - about $60 \%$ in 2003 and $76 \%$ in 2006 . Students top the chart in terms of use $-79 \%$ to $77.5 \%$-, both largely overrepresented in relation to the general population, which is consistent with Careto's account of age and info-literacy being the main traits of GEOTA's partners.

According to Diani, there are reasons to believe the use of ICT changes political activism, strengthening ties between local and national branches of one same NGO, as well as between NGOs (2001, p. 117). In Portugal, ICTs have played an important role in the intensification of communicative ties between NGOs, allowing for an easier and faster exchange of information (Vasconcelos, 2002, p. 139). In this regard, Joanaz de Melo stated "nowadays, no environmental activist can do without e-mail, Internet and mobile phone", while Careto upholded a position confirming Van de Donk's and Rucht's insight on cost and ease of use (2002):

"E-mail is, without a doubt, the preferential means of communication. Since its introduction, a great deal of our communicative practice went from paper and telephone to e-mail message. Electronic communication surpassed all other forms, without a doubt, especially in terms of the number of people who can be successfully contacted at the same time".

On the other hand, the use of ICTs had an underlying resource management rationale. According to Ferreira, its use was "the solution Quercus found to minimize costs, both in terms of labor and connections". At GAIA, conventional mail is used only on occasion, and a statutory revision is due to allow for General Assemblies to be summoned by e-mail. Its use of this form of communication is so widespread that no record of their projects is kept on paper, and meetings on a daily basis would not be possible.

Nevertheless, despite the intensity of this use, GAIA's space of places remains decisive in relation to its space of flows: according to Baptista, decisions arising from face-to-face meetings outnumber those made through email.

Prospectively, a more effective use of ICTs by LPN is still possible, for example, to supply information internally or to empower its action: "LPN is meeting a reasonable minimum, but it is still far from fully exploring ICT potential'. GEOTA's record on the matter can't be improved until financial sustainability is attained, while Quercus' challenge in promoting ICT use rests more on the end-user side: "The problem is that NGOs are made of people and the involvement of a greater number of people is absolutely vital to increase their ability". Careto (GEOTA) deepens this understanding by pointing out that "paper is used only for formal issues or those imposed by statutory regulation", and Joanaz de Melo when stating that "replacing paper with e-mail is not more frequent since paper is irreplaceable for some issues, and for other matters counterparts such as the State will simply not accept an electronic format'.

Even though ICTs are key to an organization's internal and external interactions, they are sometimes reduced by theorists to an instrumental role, underrating their structural impact (McCarthy, 1996, p. 148; Van de Donk \& Rucht, 2002). In this subject, Baptista states that ICT use has significantly changed GAIA's layout, rendering sorting out through its activity "extremely difficult without e-mair" - a point Careto also made regarding GEOTA.

ENGOs established on the Internet via a website tend to illustrate just how easier this ICT renders their action by, for instance, putting forth information on the organization's agenda, on how to join it, or how to interact with its members, as well as contacting other organizations (Norris, 2002, p. 10; Van de Donk \& Rucht, 2002) - all of which could be 
found in all four websites maintained by the ENGOs under scrutiny.

The organizational structure of an ENGO should, then, be regarded. According to Castells (2001), it often assumes a network nature, acting both locally and globally from local legitimacy frames, following the power dispersion identified by Luhmann (1993), among others. In this matter, Careto points out that GEOTA assumes "a very horizontal, thematic structure whose geometry varies according to context, need and resource availability", something which GAIA reproduces. At Quercus there is, according to Ferreira, a thematic division both, endogenous and exogenous, arising from the establishing of inter-associative networks working at local, regional and national levels.

If ENGO dynamism does not lead to more frequent, visible and fruitful ties with other institutions, namely governmental ones, that may be explained by lack of resources and/or a feeble environmental culture, which is why many times the example sought by the national ENGOs rests outside the country (Rootes, 1999, p. 5). This is the case in Portugal, with a few nuances. GEOTA's organizational structure, highly centralized, is less prone to these phenomena. In the case of Quercus, according to Ferreira, "there was recourse to these ICTs also by other organizations, a bigger set of agents, especially at the international level. Myself, I am on six or seven lists with information on a European level, and it would be impossible to take part in its debates and access this sort of information without access to the Internet". And regarding GAIA, Baptista states it would be "impossible" to keep existent channels of communication with both national and international organizations without ICTs.

\subsection{Micro-analysis: representations and frames}

Collective action should never be reduced to its political dimension. Not only is its cultural dimension decisive for its outcome, but also its effects are played at a cultural level, beyond the specific political one (Giugni, 1999 , p. 23). In this sense, given that values are action catalysts (Gibbins \& Reimer, 1999, p. 96-97), we should take into consideration the way in which collective action is mediated by Culture (Pakulski, 1995, p. 67).

It has been noted that Portugal has only recently drawn closer to EU quality of life standards. Since economical performance conditions social and environmental activism given the fact that it allows for material needs to be met and progressively replaced by nonmaterial ones (Rucht, 1999, p. 222; Kousis, 1999, p. 192), only in the last few years has Portugal seen some environmental objectives make it into the political and social agendas.

Snow's work on how collective action is a significant expression of value-based interaction structures (Melucci, 1996, p. 17) is useful when looking into the data collected by OBSERVA in 1997 and 2001, which relate individual representations on the Environment - materialized in the concern and information categories - with individual practice. According to this data, environmental issues are one of the main two problems in the country for $14 \%$ of the Portuguese population in 1997, a figure that does not significantly change in 2001, and almost half the population (45\% in 1997 and approximately the same in 2001) predicts the environmental situation in the country will worsen in the future.

However, there seems to be a tendency for the Portuguese citizens to favor passive modes of environment-related information search. From the sources included in OBSERVA's work, traditional media top the preference with $89 \%$ of answers, and $11 \%$ in the case of the Internet. Only 15\% revealed contacting ENGOs, a striking figure since in 1997 they were actually the kind of institutions regarded as one of the trust worthiest sources in this subject.

As a result, in 2001 about $62 \%$ of the inquired citizens considered themselves to be little or not at all informed regarding the subject, while only $34 \%$ stated they knew enough about it - figures which fluctuate according to age and literacy in terms of an increase within the younger people.

This passiveness resonates with the environmental practice of Portuguese citizens: even though in 1997 awareness translated into a high sympathy for the Green agenda $(70 \%)$, it did not produce significant 
participation or activism (less than 5\%) - a tendency common to that identified in 2001, a year in which the sympathy for the Green cause increased to $80 \%$.

Oddly, one of the reasons pointed out in 1997 for this meager activism was lack of information $(40 \%)$, followed closely by deficient civic education (25\%). In this regard, Baptista underlined the importance of nonexistent traditions in volunteering, while Joanaz de Melo stated "ICTS demand some pro-activeness from users: people are required to want to put it to some use".

\subsection{Sum-up}

From the preceding it is possible to draw a few regularities regarding the Portuguese ENGOs, their use of ICTs, and how such use affects the former.

First of all, their activity is heavily dependent on volunteer work, often translated into thematic matrices or frames that can be considered a project-based kind of action, confirming Melucci's insight of collective action as an analysis object that need be decomposed as a starting point (Melucci, 1996, p. 383). On the other hand, since these organizations do not possess direct access to the political system, the use of lateral strategies such as the exercise of indirect political influence via public opinion is of the utmost importance, something that can be seen in the Portuguese ENGOs (McCarthy, Smith \& Zald, 1996, p. 291; Rucht, 1999, p. 211).

The activity of these ENGOs also includes establishing networks with other national and international partners, confirming Tarrow's and Touraine's assessment, according to which these organizations summon flexible resources such as cheap, technologically advance and easy-to-use media in order to create network-connected thematic campaigns (Garner, 1996, p. 385; Tarrow, 1998, p. 207-208).

It is exactly because of its informational and communicational potential that Internet becomes attractive to these NGOs, especially in the case of one of Diani's ideal-typical organizations - the politically pragmatic conservationist ENGOs, here exemplified by Quercus, operating in terms of an instrumental rationality that aims to seize the advantages arising from the use of technological developments (Diani, 1992; Atton, 2002, p. 133).

As for representations on ICT use, its positive regard is anchored on its expense cost-benefit balance, ease and speed of contact, rendering it a tool without which part - and sometimes all - of the work developed by the ENGO would not be possible.

A sum-up of the collected data goes like this:

\begin{tabular}{|c|c|c|c|c|}
\hline GOAL AND ACTIVITY & $\begin{array}{c}\text { Conservationism; } \\
\text { direct political } \\
\text { pressure; } \\
\text { education; } \\
\text { research }\end{array}$ & $\begin{array}{c}\text { Conservationism; } \\
\text { direct political } \\
\text { pressure; } \\
\text { education; } \\
\text { training; research }\end{array}$ & $\begin{array}{c}\text { Conservationism; } \\
\text { direct and } \\
\text { indirect political } \\
\text { pressure; } \\
\text { education; } \\
\text { training; research }\end{array}$ & Education \\
\hline SOCIAL REACH & National & $\begin{array}{c}\text { Local and } \\
\text { regional through } \\
\text { protocols, } \\
\text { national, } \\
\text { international }\end{array}$ & $\begin{array}{c}\text { Local, regional, } \\
\text { national e } \\
\text { international }\end{array}$ & Local and \\
transnational \\
\hline $\begin{array}{c}\text { CHANGES IN GOAL SINCE } \\
\text { USE OF INTERNET }\end{array}$ & None & None & None & None \\
\hline $\begin{array}{c}\text { ORGANIZATIONAL } \\
\text { STRUCTURE }\end{array}$ & Vertical, \\
centralized & $\begin{array}{c}\text { Horizontal, } \\
\text { project-based }\end{array}$ & $\begin{array}{c}\text { Horizontal, } \\
\text { issue-based }\end{array}$ & $\begin{array}{c}\text { Horizontal, } \\
\text { campaign-based }\end{array}$ \\
\hline NETWORKED & Yes & Yes & Yes & Yes \\
\hline & LPN & GEOTA & Quercus & GAIA \\
\hline
\end{tabular}




\begin{tabular}{|c|c|c|c|c|}
\hline $\begin{array}{c}\text { ROLE PLAYED BY } \\
\text { NATIONAL CONTEXT }\end{array}$ & Very relevant & Very relevant & Relevant & Relevant \\
\hline $\begin{array}{c}\text { ROLE PLAYED BY } \\
\text { INTERNATIONAL CONTEXT }\end{array}$ & Not very relevant & Not very relevant & Relevant & Relevant \\
\hline $\begin{array}{c}\text { ICT ENTRY MODE IN } \\
\text { ENGO }\end{array}$ & Endogenous & Endogenous & Endogenous & Endogenous \\
\hline $\begin{array}{l}\text { NEW MEDIA / OLD MEDIA } \\
\text { ARTICULATION }\end{array}$ & $\begin{array}{l}\text { ICT used for } \\
\text { everything } \\
\text { except meetings } \\
\text { and contacting } \\
\text { formal } \\
\text { counterparts }\end{array}$ & $\begin{array}{l}\text { ICT used for } \\
\text { everything } \\
\text { except meetings } \\
\text { and contacting } \\
\text { formal } \\
\text { counterparts }\end{array}$ & $\begin{array}{c}\text { ICT used for } \\
\text { everything } \\
\text { except contacting } \\
\text { formal } \\
\text { counterparts }\end{array}$ & $\begin{array}{l}\text { ICT used for } \\
\text { everything } \\
\text { except meetings } \\
\text { and contacting } \\
\text { formal } \\
\text { counterparts }\end{array}$ \\
\hline $\begin{array}{c}\text { CHANGES IN } \\
\text { COUNTERPARTS SINCE } \\
\text { USE OF ICT } \\
\end{array}$ & Residual & $\begin{array}{c}\text { Following } \\
\text { changes in } \\
\text { society }\end{array}$ & $\begin{array}{l}\text { Following } \\
\text { changes in } \\
\text { society }\end{array}$ & Residual \\
\hline ICT ROLE & $\begin{array}{c}\text { Instrumental as a } \\
\text { communication } \\
\text { tool }\end{array}$ & $\begin{array}{c}\text { Instrumental as a } \\
\text { communication } \\
\begin{array}{c}\text { and development } \\
\text { tool }\end{array}\end{array}$ & $\begin{array}{c}\text { Instrumental as a } \\
\text { communication } \\
\text { tool }\end{array}$ & $\begin{array}{c}\text { Instrumental as } \\
\text { a } \\
\begin{array}{c}\text { communication } \\
\text { tool }\end{array}\end{array}$ \\
\hline ICT EFFICACY & $\begin{array}{l}\text { Impossible to } \\
\text { work without; } \\
\text { ease contact and } \\
\text { information } \\
\text { access }\end{array}$ & $\begin{array}{c}\text { Hard to work } \\
\text { without; time and } \\
\text { cost saving; } \\
\text { surpasses all } \\
\text { others in eficacy, } \\
\text { speed and } \\
\text { contact } \\
\end{array}$ & $\begin{array}{c}\text { Cost saving; } \\
\text { greater response } \\
\text { capacity; ease } \\
\text { and speeds up } \\
\text { contact and } \\
\text { action }\end{array}$ & $\begin{array}{l}\text { Impossible to } \\
\text { keep some } \\
\text { communication } \\
\text { channels } \\
\text { without; ease } \\
\text { contact }\end{array}$ \\
\hline $\begin{array}{c}\text { ICT PROSPECTIVE USE } \\
\text { GROWTH }\end{array}$ & Very large & $\begin{array}{l}\text { Large, depending } \\
\text { on availability of } \\
\text { financial } \\
\text { resources }\end{array}$ & $\begin{array}{l}\text { Large, depending } \\
\text { on availability of } \\
\text { human resources }\end{array}$ & Small \\
\hline
\end{tabular}

Figure 1: Summary

\section{Conclusion}

Activism, especially of an environmental nature, has been one of the analytical feuds for assessing societal dynamics, as well as society's pervasiveness and response to technology. The analytical triad followed in this paper showed, first of all, that despite the impact of ICTs in society, and specifically in political and environmental activism, the focus should always be the user and its characteristics, which come to terms with the nature of these technical objects in an interdependent process that changes both of them.

Following that triad, and going down a macro-social approach, there is a case to be made about the way in which a highly centralized Portuguese political system, where no significant Green Party exists, is not so open to the Green agenda (Rucht, 1999, p. 220; Soromenho-Marques, 2002, p. 106). Vasconcelos was also adamant in pointing out the institutional blockage around the Vasco da Gama bridge dossier, where it became visible that cooperation between highly centralized decision-marking processes in political institutions and ad-hoc project-based action in ENGOs still faces brow-raising challenges (Vasconcelos, 2002, p. 132).

On a medium-range approach, part of the success in recent ENGO action does come from its ability to adapt to the current technological paradigm (Castells, 1997). Internet use by the Portuguese organizations included in this work did allow for the exercise of pressure over elected officials and political elites, the establishing of contact and cooperation networks with other organizations vis-à-vis the coordination of mobilization and action strategies, and the broadcasting of 
agendas through the media. However, such use has not prompted structural changes in ENGOs in Portugal, mainly given the national info-literacy record and late introduction of post-modern values such as environmentalism - the most common scenario found being Internet use for ends similar to those where earlier technology was called for. Although tools such as e-mail have become standard in the work of these organizations, the truth is ENGO structure in this matter remains, thus, a variable depending much more on goals and nature of resources (both human and financial), be it the ENGOs' or their counterparts', and not so much the nature of ICTs themselves. Knowledge of the latter's potential is far greater than the actual use they're put to (Kutner, 2000).

Regarding the micro-level approach, since social actors mould their representations conditioned by a specific historical context, it was shown how ENGOs' action repertoires depend, on one hand, on the Portuguese people's views on environmental risks and individual action towards changing practices, and on the other hand, on ENGOs members' cultural interpretative devices, namely representations of the Green agenda and their organization's goal but also representations of what ICTs can be used to in that regard (Rocher, 1977-1979, p. 32; Zald, 1996, p. 266-270). This was the case with the interviewees in this work, which had very positive feedback to give regarding ICT use both current and potential - in terms of its efficacy, but who only had something to say regarding their own environmentally driven action when involved in such organizations.

Thus, it is the context - political, technological and cultural - in which these ENGOs are operating that frames and constraints their action (specifically the way they incorporate ICTs in it), and not so much the nature of ICTs themselves (in this case, the Internet), to the extent that no case can be made on a relevant connection between degree of political pragmatism/radicalism and intensity/extensity of ICT use.

\section{References}

AA. VV. (2000). Ciberfaces: Internet, Interfaces do Social, ISCTE. Retrieved October 31, 2002 from www.cav.iscte.pt Atton, C. (2002). Alternative Media. London; Thousand Oaks, CA: Sage Publications.

Cardoso, G. (1998). Para uma sociologia do ciberespaço: comunidades virtuais.em português. Oeiras: Celta Editora.

Castells, M. (1997). The Power of Identity: The Information Age: Economy, Society and Culture, Volume II, Oxford: Blackwell.

Castells, M. (2001). The Internet galaxy - Reflections on the Internet, Business, and Society. London: Oxford University Press.

Crook, S. \& Pakulski, J. \& Waters, M. (1992). Postmodernization - change in advanced societies. London: Sage Publications.

Dalton, R. (1993). The Environmental Movement in Western Europe. In S. Kamieniecki (Ed.), Environmental politics in the international arena: movements, parties, organizations and policy. State University of New York Press.

Dalton, R. (1995). Strategies of Partisan Influence: West European Environmental Groups. In C. Jenkins \& B. Klandermans (Eds.), The Politics of Social Protest - Comparative Perspectives on States and Social Movements. University of Minnesota Press.

Diani, M. \& Eyerman, R. (1992). The Study of Collective Action: Introductory Remarks. In M. Diani \& R. Eyerman (Eds), Studying Collective Action. London: Sage.

Diani, M. (2001). Virtual an real. In F. Webster (Ed.), Culture and Politics in the Information Age - A new politics? London: Routledge

Epstein, B. (1991). Political Protest and Cultural Revolution: Nonviolent Direct Action in the 1970s and 1980s. Berkeley: University of California Press.

Garner, R. (1996). Contemporary movements and ideologies. New York: McGraw-Hill.

GEOTA (2002). Tecnologias de Informação para o GEOTA. Internal strategy definition document.

Gibbins, J. \& Reimer, B. (1999). The politics of Postmodernity: An Introduction to Contemporary Politics and Culture. London: Sage Publications.

Giugni, M. (1999). How Social Movements Matter: Past Research, Present Problems, Future Developments. In M. Giugni \& D. McAdam \& C. Tilly (Eds.), How Social Movements Matter. University of Minnesota Press. 
Kousis, M. (1999). Sustaining Local Environmental Mobilizations: Groups, Actions and Claims in Southern Europe. In C. Rootes (Ed.), Environmental Movements: Local, National and Global. London: Frank Cass \& Co.

Kutner, L. (2000). Environmental Activism and the Internet. Electronic Green Journal, 12. Retrieved December 20, 2008 from http://egi.lib.uidaho.edu/index.php/egi/article/view/2774/2732

Luhmann, N. (1993). A Improbabilidade da Comunicação. Lisboa: Vega.

Maheu, L. (1993). Postmodernité et mouvements sociaux. In M. Audet \& H. Bouchikhi (Eds), Structuration du social et modernité avancée - autour des travaux d'Anthony Giddens. Saint-Foy: Les Presses de l'Université Laval.

Maheu, L. (Ed.) (1995). Social movements and social classes - the future of collective action. London: Sage Publications.

Mansell, R. (2001). New Media and the Power of Networks. Paper presented at the London School of Economics and Political Science.

Marx, K. (1963). The Eighteenth Brumaire of Louis Bonaparte. New York: International Publishers.

McCarthy, J. (1996). Constraints and opportunities in adopting, adapting, and inventing. In D. McAdam \& J. McCarthy \& M. Zald (Eds.), Comparative Perspectives on Social Movements: Political Opportunities, Mobilizing Structures, and Cultural Framings. Cambridge University Press.

Melucci, A. (1995). Individualisation et globalisation: au-delà de la modernité? In F. Dubet \& M. Wieviorka (Eds), Penser le Sujet. Paris: Fayard.

Melucci, A. (1996). Challenging Codes: Collective Action in the Information Age. Cambridge University Press.

Norris, P. (2002). Democratic Phoenix: Reinventing Political Activism. Cambridge University Press.

OberCom (2007). Anuário da Comunicação 2005-2006. Lisboa: OberCom.

OberCom (2008). A Internet em Portugal 2003-2006. Lisboa: OberCom.

Pakulski, J. (1995). Social movements and class: the decline of the marxist paradigm. In L. Maheu (Ed.), Social movements and social classes - the future of collective action. London: Sage Publications.

Quivy, R. \& Van Campenhoudt, L. (1998). Manual de investigação em ciências sociais. Lisboa: Gradiva.

Rocher, G. (1977-1979). Sociologia Geral. Lisboa: Editorial Presença.

Rootes, C. (1999). Environmental Movements: from the local to the global. In C. Rootes (Ed.), Environmental Movements: Local, National and Global. London: Frank Cass \& Co.

Rucht, D. (1999). The Impact of Environmental Movements in Western Societies. In M. Giugni \& D. McAdam \& C. Tilly (Eds.), How Social Movements Matter. University of Minnesota Press.

Silverstone, R. (2002). Why Study the Media? September 11 and the ethics of distance. Paper presented at ISCTE.

Soromenho-Marques, V. (2002). The Portuguese Environmental Movement. In L. Vasconcelos \& I. Baptista (Eds.), Environmental Activism in Society. Luso-American Foundation.

Tarrow, S. (1996). States and opportunities: the political structuring of social movements. In D. McAdam \& J. McCarthy \& M. Zald (Eds.), Comparative Perspectives on Social Movements: Political Opportunities, Mobilizing Structures, and Cultural Framings. Cambridge University Press.

Tarrow, S. (1998). Power in movement - social movements and contentious politics. Cambridge: University Press.

Van de Donk, W. \& Rucht, D. (Eds) (2002). Cyberprotest: New Media, Citizenship and Social Movements. London: Routledge.

Vasconcelos, L. (2002). The Portuguese Environmental Movement. In L. Vasconcelos \& I. Baptista (Eds.), Environmental Activism in Society. Luso-American Foundation.

Webster, F. (2001). A new politics? In F. Webster (Ed.), Culture and Politics in the Information Age - A new politics? London: Routledge.

Zald, M. (1996). Culture, ideology and strategic framing. In D. McAdam \& J. McCarthy \& M. Zald (Eds.), Comparative Perspectives on Social Movements: Political Opportunities, Mobilizing Structures, and Cultural Framings. Cambridge University Press.

\section{About the Author}

Pedro Pereira Neto

Pedro Pereira Neto is PhD student at ICS-UL, holds a MA in Communication (ISCTE), and a BA in Sociology (ISCTE). He is also the current Journal Manager for OBS Obercom (http://obs.obercom.pt) 